\title{
Integrated scoring of salinity stress on agro-morphometric and seed storage proteins in barley landraces
}

\author{
Murad Ali ${ }^{1,2 *}$, Manzoor Hussain ${ }^{2}$, Saeed Abdullah ${ }^{1}$, Waqar Khan ${ }^{1}$ and \\ Mohammad Nisar ${ }^{1}$ \\ 1. Department of Botany, University of Malakand, Dir lower, Khyber Pakhtunkhwa-Pakistan \\ 2. Department of Botany, Hazara University Mansehra, Khyber Pakhtunkhwa-Pakistan \\ *Corresponding author's email: muradsahil77@gmail.com \\ Citation \\ Murad Ali, Manzoor Hussain, Saeed Abdullah, Waqar Khan and Mohammad Nisar. Integrated scoring of \\ salinity stress on agro-morphometric and seed storage proteins of barley landraces. Pure and Applied Biology.
} Vol. 9, Issue 1, pp963-978. http://dx.doi.org/10.19045/bspab.2020.90011

\begin{tabular}{llll}
\hline \hline Received: 13/06/2019 & Revised: 24/08/2019 & Accepted: 02/09/2019 & Online First: 16/09/2019 \\
\hline \hline
\end{tabular}

\section{Abstract}

Abiotic stress factors, especially high temperatures and salinity, represent the major constraints limiting agricultural production. In present investigation barley forty selected lines was treated in pods at three salt concentrations $(25,50$ and $75 \mathrm{mM} \mathrm{NaCl})$ and one control line. In present investigation the maximum salinity affect the yield, spike and total biomass of the plant. For the genetic diversity among barley lines two method were applied morphological evaluation under IPGRI 1994 descriptor and protein profiling, a significant genetic variation index were occur in qualitative traits on the basis of frequency distribution. As result two clusters was obtained at linkage distance 25. Cluster-1 contains 39 lines while cluster- 2 contains only 1 line. In protein profiling a total of 12 bands were observed in which 10 bands were polymorphic and two bands 1 and 9 were monomorphic. the genetic diversity on band 1 is $0.65 \%$, band $2(0.58 \%)$, band 3 and $4(0.45 \%)$, band $5(0.50)$, band $6(0.55)$, band $7(0.60)$, band $8(0.28)$, band $9(0.68)$, band $10(0.75)$, band $11(0.70)$, band $12(0.65)$, these bands were further divided into three zone on the basis of molecular weight. Zone one contain four bands (band 12,11,10,9), zone two contain four (band 8, 7,6,5), zone three also contain four bands (band 4, 3, 2, 1). Band 5 dominantly present in zone two bands 10 is dominantly present in zone one which show significant genetic diversity among barley genotypes, a dendrogram tree were also construct for protein bands. As result three clusters were obtained at linkage distance 25 . Cluster- 1 contains 16 genotypes cluster- 2 contains only 14 genotype and cluster-3 contains 10 genotypes out up 40.

Keywords: barley; morphometric traits; Salinity; SDS-PAGE; Seed Storage Proteins

\section{Introduction}

Barley (Hordeum vulgare L.) is one of the old and an important winter cereal crop for the people living it high altitudes and urban areas of agriculture economy base countries like Pakistan [1]. Barley is also distributed world widely in temperate areas. This cereal crop belongs to family poaceae which also contains several edible cereals and forages as well as about 350 wild species. Hordeum vulgare is also in the criteria one of major cereals crops of the world on the base of, it contains $80 \%$ of carbohydrates, on ancient time people uses the recipe of Barley before battles in the field. Modern biochemistry techniques base experiment illustrated that due to consistency of non-starch polysaccharides 
in Barley also known as glucans is use to lower the blood serum cholesterol level in humans [2]. The seeds of Hordeium vulagri grain also consist, approximately $10-17 \%$ protein, 2-3\% lipids, $65-68 \%$ starch (main carbohydrate), $1.5-2.5 \%$ minerals and about 4-9\% B glucans while soluble dietary fibers present $3-20 \%$ in total of $11-34 \%$ dietary fibers. B glucans are the major non-starch polysaccharides in barley grain [2].

Nowadays, barley is an important crop plant globally. It is mainly used a raw material for the production of malt. In about $59 \%$ and $14 \%$ of total barley used as feed and an industries, respectively [3]. Barley is a chief crop for food in mountain areas of Asia and Northern Africa. As barley have high content of soluble dietary fibers, and its proven health effects have improved the status of barley as a food element [4]. According to Fischbeck, 2002 barley is also used in beer production, approximately 18 million tons of barley need for production of 1.3 billion liters of beer per year. Barley is ranked as fourth cereal crop after maize, wheat and rice in the world [5] while at rank sixth in Pakistan. barley has been given least importance in Pakistan among the cereal crops because it is been cultivated only in marginal lands i.e drought and saline condition therefore, the area and production of barley is decrease day by day. Barley is the second most important winter cereal in Pakistan. It occupies an area of 84.1 thousand hectares with production of 71.4 thousand tones. The average yield is $945 \mathrm{~kg}$ per hectare [6]. Although barley (Hordeum vulgare L.) is regarded as salt tolerant among crop plants, its growth and plant development is severely affected by ionic and osmotic stresses in salt-affected soils Barley (Hordeum vulgare L.) is rated as salt tolerant among the crop plants. [7] reported in his article that salt tolerant barley genotype 'Afzal' produced higher dry mass compared to salt sensitive genotype under salt stress conditions (200 $\mathrm{mM} \mathrm{NaCl}$ ) and higher tolerance in genotype Afzal was associated with a higher $\mathrm{K}+/ \mathrm{Na}+$ ratio of the shoots. $\mathrm{NaCl}$ toxicity is largely attributed to the effects of $\mathrm{Na}^{+}$and only rarely to those of $\mathrm{Cl}^{-}$[7]. Under saline field conditions, the plants may be subjected to different salt levels and ionic stresses.

However, a great genetic variation exists for salt tolerance in its cultivars [8]. Very little quality research has been carried out for most of this worldwide germplasm. The research described in this article aim to identify those lines which show resistant to different salinity concentration and commercialize barley saline lines in the country.

\section{Materials and methods}

In the present study 40 selected lines were selected from the population of Hordeium vulgare which show adaptation, adaptability to climatic changes and show consistency in the yield contributing traits and have a multivariate fluctuation response to climatic changes were selected. The experimental work is designed in two phase Glass house and protein profiling of saline Lines.

\section{Field experiment}

Field experiment was performed in the glass house, Botanical garden University of Malakand. The 40 and one control line were sown in the 41 pots, the pots were filled from soil of botanical garden up to one third part of the pot .Out of forty one pots forty were treated with salinity and one was control. The pots were put on the iron try inside the glass house. The selected lines was planted on $12^{\text {th }}$ October 2017. In each pot 3-4 seed were planted. Irrigation was applied before and after the sowing, to obtain healthy and vigorous plants, the crop was not sprayed for any pesticide. Salinity treatment was started from $2^{\text {nd }}$ week after germination. Plants were exposed to 25 $\mathrm{mM} \mathrm{NaCl}$ for 1 week, then the concentration was first increased to $50 \mathrm{mM}$ $\mathrm{NaCl}$ for $2^{\text {nd }}$ week and then to $75 \mathrm{mM} \mathrm{NaCl}$ (moderate salinity level, which may be expected in the field according to [9]. Salt concentration was raised in $25 \mathrm{mM}$ increments to diminish any shock effect of a sudden osmotic stress [10]. Some plants 
remained in $75 \mathrm{mM} \mathrm{NaCl}$ for 3 weeks to allow a study of long-term effects of salinity on plant growth and chlorophyll content. All treatments were compared with similar aged control plants maintained in the standard solution. and to note the agromorphometric traits of these lines like quality base and quantity base parameters such as Lemma colour growth habit, stem pigmentation, auricle pigmentation, photoperiod sensitivity, kernel covering, spike density, Alurone colour, grain colour, lemma colour, lemma awn, lemma awn barbs, glume and glume, glume colour, lemma type, length of rachilla hairs, row number. 9 quantitative traits include day to germination, days to flowering, days to maturity, plant height, biomass per plant, seed per spike, spike length, 100 seed weight and harvest index an all these traits on the base of their quality base traits and quantity base traits cataloged under the IPGRI 1994 descriptor.

\section{Biochemical characterization}

For protein extraction five healthy seeds from each accession were for polyacrylamide gel electrophoresis through SDS-PAGE. For this purpose the grain was grind to fine powder with the help of pestle and mortal. A total of $0.3 \mathrm{~g}$ of powder was taken from each sample into the eppendrof tube. Add $700 \mu 1$ protein extraction buffer to the eppendrof tube and then vertex to homogenize. After vertexing the sample were then centrifuged at $15000 \mathrm{rpm}$ for 40 minute at $40 \mathrm{C}^{\circ}$. Then $12 \mu \mathrm{l}$ of each sample loaded to the wells of the $12.5 \%$ polyacrylamide gel congaing separation gel (0.4\% SDS, 3M Tris-HCL and PH 9) and stacking gel $(0.4 \%$ SDS, $0.4 \mathrm{M}$ Tris-HCL, $\mathrm{PH}$ 3.4). The gel were then kept into the electrode buffer solution containing (0.125\% SDS, 129 M Glycine, $0.025 \mathrm{M}$ Tris and run it on $80 \mathrm{~V}$ for $5 \mathrm{hrs}$. The gel were then transfer to staining solution composed of 500ml Methanol, 60ml Acetic acid, 2.25g coosmassie briliant blue CBB, $460 \mathrm{ml}$ Distilled water, and run the electric shaker approximately for 50 mins to stained the protein bands. The gel was then kept in de-staining solution over into 8 hours, until the blue background becomes disappear and bands become visible. The protein data were recorded in MS excel 2016. The presence of bands shown by 1 while absence of represented by 0 .

\section{Results}

During the present study, 40 and 1 control Line of barley was studied; a total of 25 parameters were noted in the present investigation. The agro-morphological parameters were further divided into i.e Qualitative and Quantitative. Frequency distribution for agro-morphological traits including spike density, glume awn, lemma awn barbs, awn colour, lemma awn hood, length of rechilla hair, lemma colour, aurical pigmentation, photo period sensitivity, grain colour, stem pigmentation, kernel covering, row number, growth habit, glume colour, lemma type, and also their quantity base traits include days to germination, days to flowering, and days to maturity, 100 seed weight, and spike length, seed per spike, plant height, plant biomass, and harvest index.

\section{Qualitative traits \\ Spike density}

On the basis of spike density barley genotype show variation from each other, on the basis of spike density there are three type of spike density (lax, intermediate, dense) were observed in 40 genotype of barley, the lax was (47.55\%) frequency 19 , intermediate $(27.5 \%)$ frequency 11 , and dense $(25 \%)$ frequency which show divergence among the genotypes, as described in (Table 1).

Table 1. Frequency distribution of $\mathbf{1 6}$ qualitative traits of studied lines

\begin{tabular}{|c|c|c|c|c|}
\hline Character & Categories & codes & frequency & \%age \\
\hline \multirow{2}{*}{ Spike density } & Lax & 3 & 19 & 47.5 \\
\cline { 2 - 5 } & Intermediate & 5 & 11 & 27.5 \\
\hline
\end{tabular}


Ali et al.

\begin{tabular}{|c|c|c|c|c|}
\hline & Dense & 7 & 10 & 25 \\
\hline \multirow{4}{*}{ Glume awn } & Length of glume and awn shorter than kernel & 1 & 7 & 17.5 \\
\hline & Length of glume and awn as long as & 2 & 14 & 35 \\
\hline & Length of glume and awn longer than kernel & 3 & 18 & 45 \\
\hline & Length of glume and awn nearly twice than kernel & 4 & 1 & 2.5 \\
\hline \multirow{3}{*}{$\begin{array}{l}\text { Lemma awn } \\
\text { barbs }\end{array}$} & Smooth & 3 & 9 & 22.5 \\
\hline & Intermediate & 5 & 6 & 15 \\
\hline & Rough & 7 & 25 & 62.5 \\
\hline \multirow{5}{*}{ Awn colour } & Amber/white & 1 & 36 & 90 \\
\hline & Yellow & 2 & 2 & 5 \\
\hline & Brown & 3 & 1 & 2.5 \\
\hline & Reddish & 4 & 1 & 2.5 \\
\hline & Black & 5 & 0 & 0 \\
\hline \multirow{3}{*}{$\begin{array}{c}\text { Lemma } \\
\text { awn/hood }\end{array}$} & Awnless & 1 & 0 & 0 \\
\hline & Awnleted & 2 & 0 & 0 \\
\hline & Awned & 3 & 40 & 100 \\
\hline \multirow{2}{*}{$\begin{array}{l}\text { Length of } \\
\text { rachilla hair }\end{array}$} & Long & 1 & 21 & 52.5 \\
\hline & Short & 2 & 19 & 47.5 \\
\hline \multirow{4}{*}{$\begin{array}{l}\text { Lemma } \\
\text { colour }\end{array}$} & Normal & 1 & 36 & 90 \\
\hline & Tan/red & 2 & 1 & 2.5 \\
\hline & Purple & 3 & 1 & 2.5 \\
\hline & Black & 4 & 2 & 5 \\
\hline \multirow{4}{*}{$\begin{array}{c}\text { Auricle } \\
\text { pigmentation }\end{array}$} & Green & 1 & 36 & 90 \\
\hline & Pale purple & 2 & 2 & 5 \\
\hline & Purple & 3 & 2 & 5 \\
\hline & Dark purple & 4 & 0 & 0 \\
\hline \multirow{4}{*}{$\begin{array}{c}\text { Photo period } \\
\text { sensitivity }\end{array}$} & Very low or no visible sign of sensitivity & 1 & 5 & 12.19 \\
\hline & Low sensitive & 3 & 28 & 68.29 \\
\hline & Intermediate & 5 & 4 & 9.75 \\
\hline & High sensitive & 7 & 4 & 9.75 \\
\hline \multirow{4}{*}{ Grain colour } & White & 1 & 38 & 95 \\
\hline & Tan/red & 2 & 1 & 2.5 \\
\hline & Purple & 3 & 0 & 0 \\
\hline & Black & 4 & 1 & 2.5 \\
\hline \multirow{3}{*}{$\begin{array}{c}\text { Stem } \\
\text { pigmentation }\end{array}$} & Green & 1 & 4 & 9.75 \\
\hline & Purple (base only ) & 2 & 5 & 12.19 \\
\hline & Purple (half or more ) & 3 & 32 & 78.04 \\
\hline \multirow{3}{*}{$\begin{array}{c}\text { Kernel } \\
\text { covering }\end{array}$} & Naked grain & 1 & 0 & 0 \\
\hline & Semi covered grain & 2 & 0 & 0 \\
\hline & Covered grain & 3 & 40 & 100 \\
\hline \multirow{3}{*}{ Row number } & Tow rowed & 1 & 2 & 5 \\
\hline & Six rowed & 5 & 2 & 5 \\
\hline & Irregular & 3 & 36 & 90 \\
\hline \multirow{3}{*}{ Growth habit } & Prostrate & 3 & 3 & 7.31 \\
\hline & Intermediate & 5 & 13 & 31.70 \\
\hline & Erect & 7 & 25 & 60.97 \\
\hline \multirow{4}{*}{$\begin{array}{l}\text { Glume } \\
\text { colour }\end{array}$} & White & 1 & 37 & 92.5 \\
\hline & Yellow & 2 & 2 & 5 \\
\hline & Brown & 3 & 1 & 2.5 \\
\hline & Black & 4 & 0 & 0 \\
\hline \multirow{3}{*}{ Lemma type } & No lemma teeth & 1 & 17 & 42.5 \\
\hline & Lemma teeth & 2 & 21 & 52.5 \\
\hline & Lemma hair & 3 & 2 & 5 \\
\hline
\end{tabular}




\section{Glume awn}

The glume with awn length compare to kernel, length of glume and awn shorter then kernel is present in $(17.5 \%)$ with frequency 7 , length of glume and awn as long as kernel as present in (35\%) with frequency 14, length of glume and awn longer then kernel is present in (45\%) with frequency 18 , length of glume and awn twice longer then kernel is present in $(2.5 \%)$ with frequency 1 , which show variation among the landraces of barley.

\section{Awn barbs}

Among the 40 genotype smooth awn barb is present in $(22.5 \%)$ with frequency 9 , intermediate $(15 \%)$ with frequency 6 , and rough are found in $(62.5 \%)$ with frequency 25 , which show variation in barley landraces.

\section{Awn colour}

In case of awn colour white colour found in $(90 \%)$ with frequency 36 , yellow colour is present in $(5 \%)$ frequency 2 , brown colour in $(2.5 \%)$ frequency 1 , black colour is present in $(2.5 \%)$ with frequency 1 and reddish colour were not found in any landraces.

\section{Lemma awn}

There is no variation found among the 40 landraces all the landraces had awned (100\%).

\section{Length of rechilla hair}

Length of rechillah hair are two type, long hair is present in (52\%) with frequency 21 , and short hair were found in $(47 \%)$ frequency 19.

\section{Lemma colour}

A wide range of variability found in lemma colour normal colour is found in 36 landraces $(90 \%)$ tan red is present in $(2.5 \%)$ frequency 1 , purple colour had $(2.5 \%)$ frequency 1 , black colour is present in $(5 \%)$ frequency 2 .

\section{Auricle pigmentation}

On the basis of auricle pigmentation green colour were found in $(90 \%)$ with frequency 36 , pale purple had (5\%) frequency 2 , purple colour also found in (5\%) frequency 2 , while dark purple colour were not found in any landraces.

\section{Photoperiod sensitivity}

On the basis of photoperiod sensitivity very low or in visible sign is present in $(12.5 \%)$ with frequency 5 , low sensitivity is present in $(67.5 \%)$ frequency 27 , intermediate with frequency $(10 \%) 4$, and high sensitivity is found in (10\%) with frequency 4.

\section{Grain colour}

Among the 40 landraces white colour grain is present in (95\%) with frequency 38,tan red were with frequency $(2.5 \%) 1$, black is present in $(2.5 \%)$ frequency 1 , while purple colour is not found in any landraces which show variation in barley landraces.

\section{Stem pigmentation}

On the basis of stem pigmentation there are three types, among the 40 landraces green is present in (10\%) with frequency 4, purple base only in $(12.5 \%)$ with frequency 5 , purple half or more is present in $(77.5 \%)$ with frequency 31 .

\section{Row number}

Among the 40 landraces tow rowed is found in $(5 \%)$ frequency 2 , six rows with $(5 \%)$ frequency 2 , irregular is present in 36 landraces (90\%).

\section{Growth habit}

There are three type of growth habit found in 40 landraces, prostrate in $(7.5 \%)$ with frequency 3 , intermediate in $(32.5 \%)$ frequency 13 , while erect is present in $(60 \%)$ which have frequency 24.

\section{Glume colour}

Among the 40 landraces white glume colour is found in $(92 \%)$ with frequency 37 , yellow is present in (5\%) frequency 2 , brown colour is found in $(2.5 \%)$ with frequency 1 , while black is not found in landraces which show variation among the landraces.

\section{Lemma type}

On the basis of lemma type there are three types, in which no lemma teeth is found in $(42.5 \%)$ frequency 17 , lemma with teeth is present in $(52.5 \%)$ with frequency 21 , while lemma with hair is found in $(5 \%)$ with frequency 2 , which show a wide variation among the landraces. 


\section{Kernel covering}

There is no variation in the kernel covering all the landraces are covered $(100 \%)$.

\section{Quantitative traits}

\section{Descriptive statistics of quantitative traits}

During the present study a wide range of variation were noted among 40 genotype, the rang of plant height is between $50 \mathrm{~cm}$ to $120 \mathrm{~cm}$. on the basis of plant height divided into three category, low (50 to $70 \mathrm{~cm}$ ), medium (71 to $90 \mathrm{~cm}$ ), and high (91 to 120 $\mathrm{cm}$ ), with mean value as 87.12 (Table 2) and sample variance 208.76. Maximum plant height was $120 \mathrm{~cm}(0.41 \%)$, minimum plant height was $50 \mathrm{~cm}(0.19 \%)$ and the $(0.39 \%)$ are medium plant height, in Days to flowering base traits these 40 lines show there different effect to salinity which range from 89 to 165 days. Days to flowering divided into three categories, early (89 to 115 days), moderate (116 to 140 days), and high (141 to 165 days) the range of days to maturity 89 to 165 days, with mean value 139.83 and sample variance 183.07 (Table 3). Maximum number of landraces was high $(0.55 \%)$ minimum number is low days to maturity $(0.05 \%)$ and $(0.4 \%)$ was intermediate while variation noted in other traits like days to maturity with their mean value difference $173.92 \%$ and sample variance $31.15 \%$ while the mean value difference of Spike length is $17.46 \%$ and $4.55 \%$ sample variance was observed. in these lines the yield contributing traits also show variance $(\mathrm{CV} \%)$ in the traits. The coefficient of variation in plant per seed is $0.42 \%, 100$ seed weight is $0.32 \%$, plant height is $0.17 \%$ while in Biomass of per plant high variation was observed $0.35 \%$ (Figure 1).

\section{Correlation analysis of quantitative traits}

Correlation was calculated by using Minitab software for quantitative traits of barley forty lines in which Days to flowering was significantly negative correlated to plant height, days to maturity was negatively correlated to plant height and strongly positive correlated to days to flowering, spike length is significantly positive correlated to plant height, days to flowering and days to maturity, plant per grain is negatively correlated to plant height and spike length and significantly positive correlated to days to flowering and days to maturity, grain per spike is strongly positive correlated to plant height $(.414 * *)$ and significantly negative correlated todays to flowering $\left(-.381^{*}\right)$ while significantly positive correlated to days to maturity $\left(.375^{*}\right)$, biomass per plant is significantly positive correlated to plant height, days to flowering, days to maturity and spike length, while negatively correlated to plant per grain and strongly positive correlated to grain per spike (.446**), 100 seed weight is positively correlated to all (Table 3 ).

Table 2. Descriptive statistics for eight quantitative characters of 40 barley genotype

\begin{tabular}{|c|c|c|c|c|c|c|c|}
\hline \multirow{2}{*}{ Parameter } & \multirow{2}{*}{ Mean } & \multirow{2}{*}{$\begin{array}{c}\text { Std. } \\
\text { Deviation }\end{array}$} & \multirow{2}{*}{$\begin{array}{c}\text { Sample } \\
\text { Variance }\end{array}$} & \multirow{2}{*}{$\begin{array}{c}\text { Standard } \\
\text { error }\end{array}$} & \multicolumn{2}{|c|}{ Range } & \multirow[b]{2}{*}{ CV\% } \\
\hline & & & & & Minimum & Maximum & \\
\hline $\mathbf{P H}$ & 87.12 & 14.45 & 208.76 & 0.72 & 54.60 & 118.00 & 0.17 \\
\hline $\mathrm{D} / \mathrm{F}$ & 139.83 & 13.53 & 183.07 & 0.73 & 89.00 & 162.00 & 0.10 \\
\hline D/M & 173.92 & 5.58 & 31.15 & 0.73 & 159.00 & 180.00 & 0.03 \\
\hline $\mathrm{S} / \mathrm{L}$ & 17.46 & 2.13 & 4.55 & 0.73 & 13.40 & 22.60 & 0.12 \\
\hline $\mathrm{p} / \mathrm{S}$ & 6.51 & 2.75 & 7.56 & 0.72 & 3.00 & 15.00 & 0.42 \\
\hline G/S & 30.63 & 8.85 & 78.29 & 0.73 & 13.00 & 46.00 & 0.29 \\
\hline Biomass & 2.49 & 0.88 & 0.77 & 0.72 & 0.75 & 5.33 & 0.35 \\
\hline $100 \mathrm{SW}$ & 3.60 & 1.16 & 1.34 & 0.73 & 0.70 & 5.76 & 0.32 \\
\hline
\end{tabular}

NOTE: $\mathrm{PH}=$ plant height, $\mathrm{DF}=$ days to flowering, $\mathrm{DM}=$ days to maturity, $\mathrm{SL}=$ spike length, $\mathrm{PS}=$ plant per seed, $\mathrm{GS}=$ grain per spike, $100 \mathrm{SW}=100$ seed weight 
Table 3. Correlation among the eight quantitative traits of 40 Lines

\begin{tabular}{|c|c|c|c|c|c|c|c|c|}
\hline & PH & D/F & D/M & L/Spike & Grain/P & Grain/S & Biomass & 100SW \\
\hline PH & 1 & & & & & & & \\
\hline D/F & -0.186 & 1 & & & & & & \\
\hline D/M & -0.011 & $.700^{* *}$ & 1 & & & & & \\
\hline Spike L & 0.182 & 0.038 & -0.136 & 1 & & & & \\
\hline Grain/P & -0.11 & 0.131 & 0.016 & -0.032 & 1 & & & \\
\hline Grain/S & $.414^{* *}$ & $-.381^{*}$ & $-.375^{*}$ & 0.151 & -0.28 & 1 & & \\
\hline Biomass & $.358^{*}$ & 0.073 & -0.113 & $.334^{*}$ & -0.178 & $.446^{* *}$ & 1 & \\
\hline 100 SW & 0.158 & 0.009 & -0.119 & 0.107 & 0.121 & 0.28 & 0.18 & 1 \\
\hline
\end{tabular}

**. Correlation is significant at the 0.01 level (2-tailed).

*. Correlation is significant at the 0.05 level (2-tailed).

Note: $\mathrm{PH}=$ plant height, $\mathrm{DF}=$ days to flowering, $\mathrm{DM}=$ days to maturity, $100 \mathrm{SW}=100$ seed weight

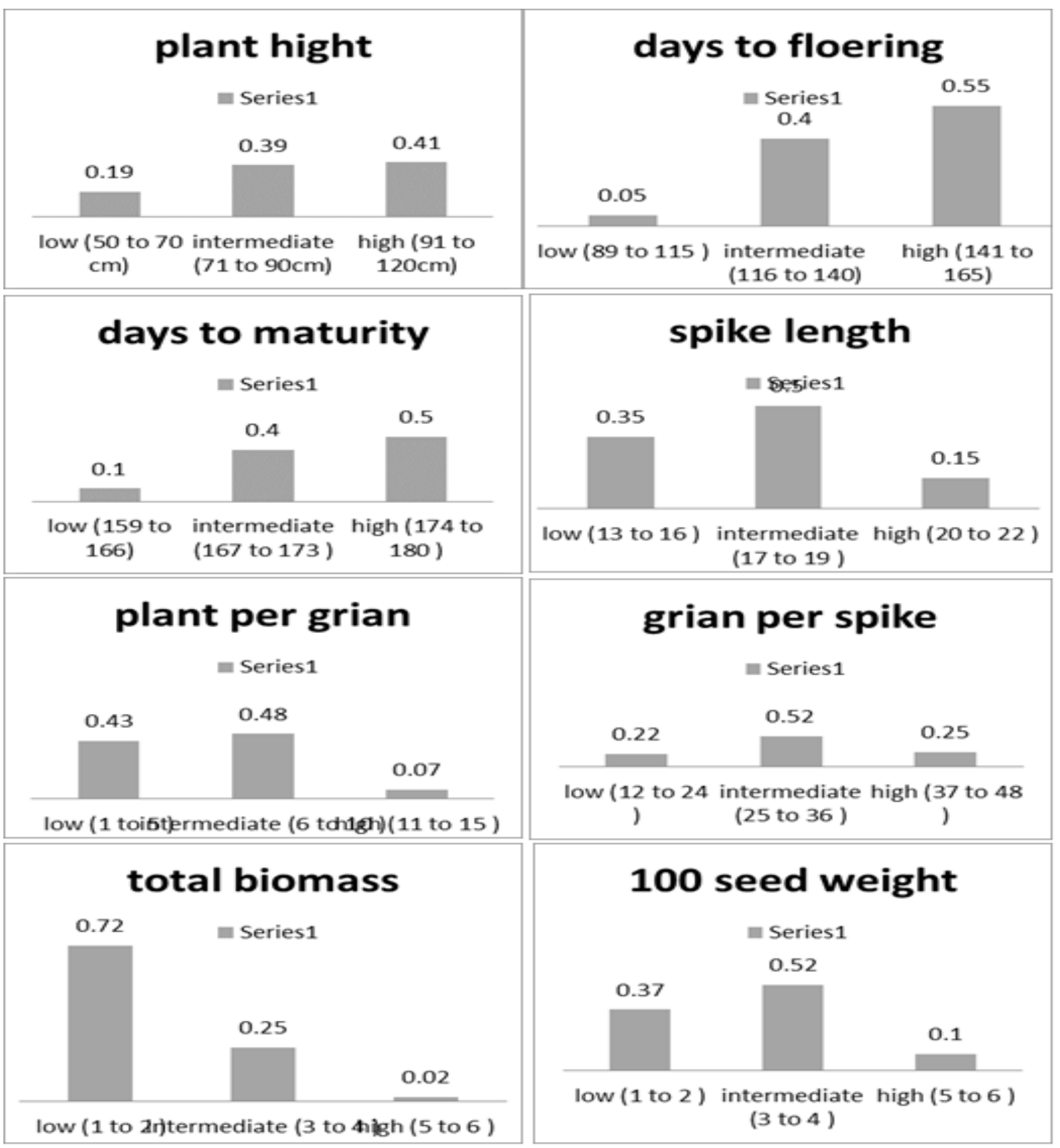

Figure 1. List of eight quantitative traits of $\mathbf{4 0}$ salinity effected charts 
Cluster analysis of agro morphological character

Cluster analysis for agro morphological character of 40 genotype of barley, PCORD was used to construct a dendrogram tree for eight Quantitative traits as shown in (Figure 2) as result two clusters were obtained at linkage distance 25. Cluster1 contains 39 genotypes and cluster 2 contains only 1 genotype. Cluster1 had (S001, S014, S004, S017, S003, S022, control, S002, S006, S023, S010, S012, S13, S019, S015, S032, S016, S020, S030, S035, S34, S021, S037, S011, S029, S36, S018, S033, S039, S025, S027, S005, S038, S007, S008, S024, S028, S040, S009, S026) cluster 2 had only one genotype S031.these genotypes are also assess through PCORD for principle component Analysis which also scatter these genotypes into two clusters similar to dendrogram tree shown in (Figure 3 ).

Protein polypeptide bands richness (PPBR)

A total of 12 protein bands were scored in Pakistani barley genotypes ranged from 10 to $180 \mathrm{kDa}$. Out of twelve bands two bands are monomorphic i.e band 1 and band 9 while the remaining bands are polymorphic. The bands were divided into three zone, zone one have molecular weight from 12 to $60 \mathrm{kDa}$ zone two have molecular weight from 60 to $120 \mathrm{kDa}$ and zone three have molecular weight from 120 to 180 $\mathrm{kDa}$. Zone one contain four bands (band 12, $11,10,9$ ), zone two contain four (band 8, 7 , $6,5)$, zone three also contain four bands (band 4, 3, 2, 1). Band 5 dominantly present in zone two bands 10 is dominantly present in zone one (Figure 4), which show significant genetic diversity among barley genotypes and provide the base in future for breeder.

Genetic diversity on the basis of proteomics

Maximum genetic diversity were observed on band 10, while minimum genetic diversity were found on band 8 , genetic diversity on band 1 is $(0.65)$, band $2(0.58)$, band $3(0.45)$, band $4(0.45)$ band $5(0.50)$, band $6(0.55)$, band 7 (0.60), band $8(0.28)$, band $9(0.68)$, band $10(0.75)$, band 11 (0.70), band $12(0.65)$.

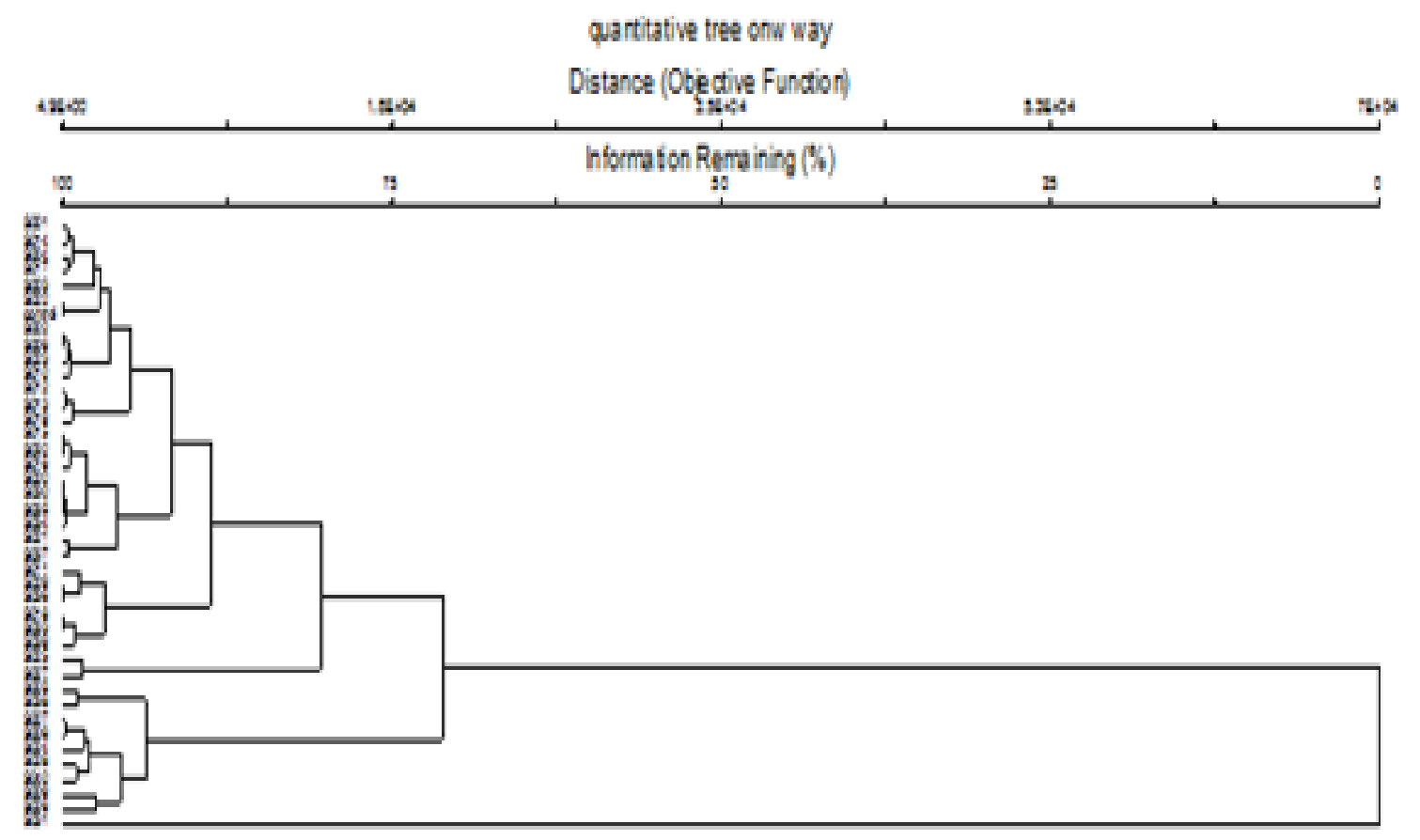

Figure 2. Morphological quantitative tree one way cluster analysis of 40 Lines used PCORD 

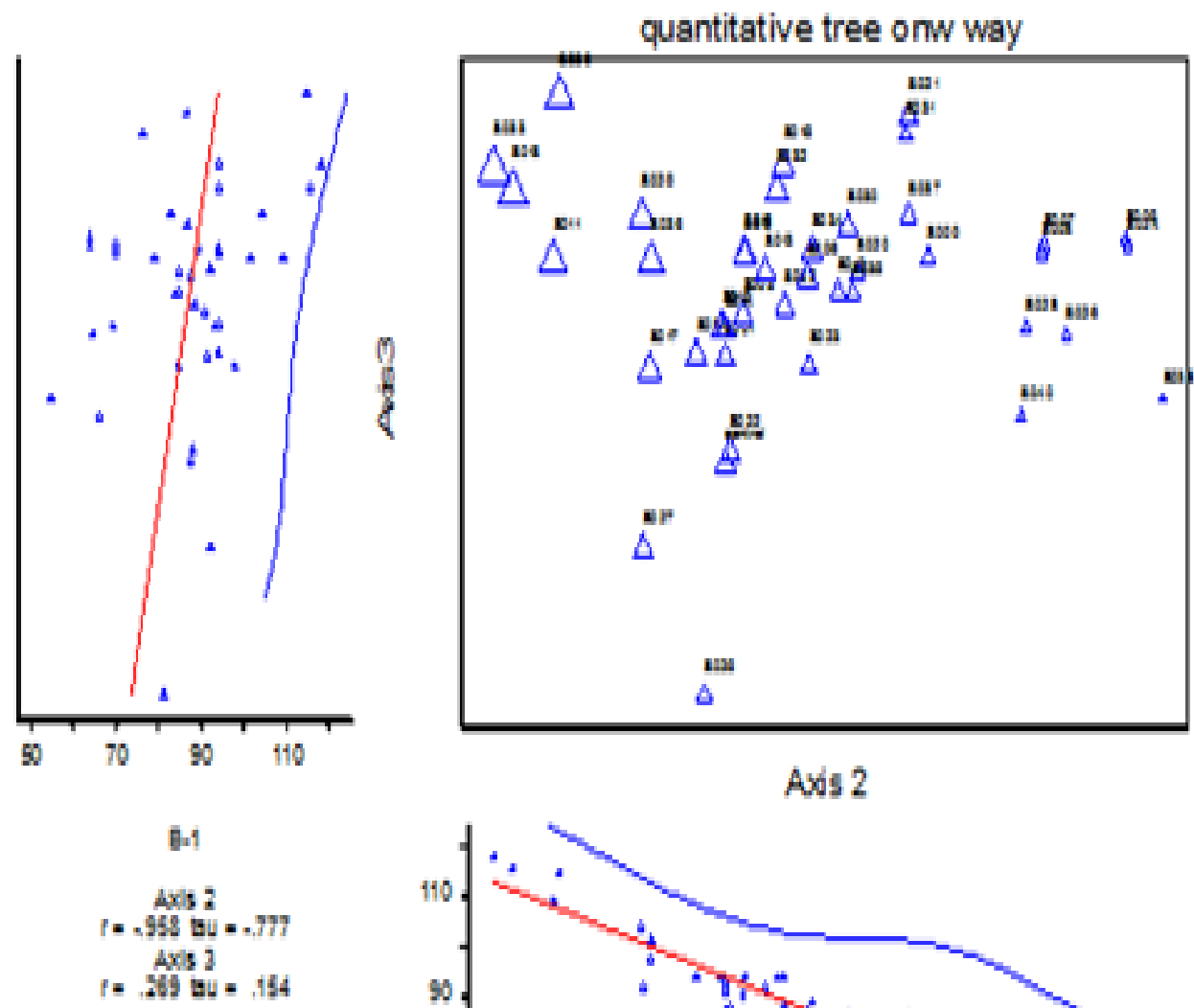

Axd 2

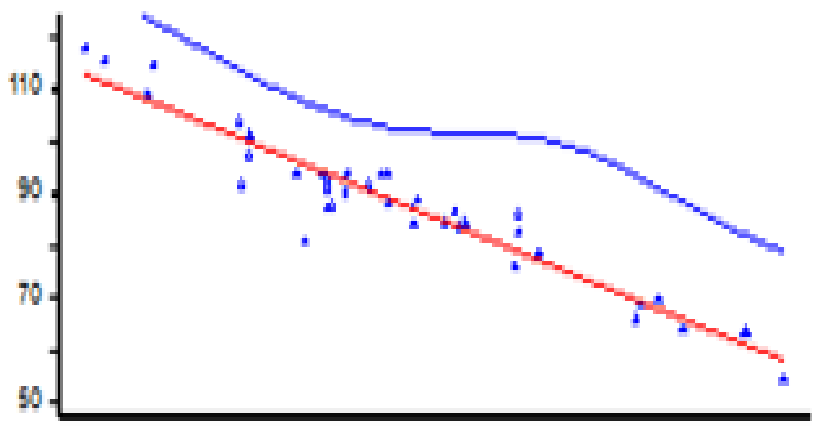

Figure 3. Scatter plot for quantitative morphological data

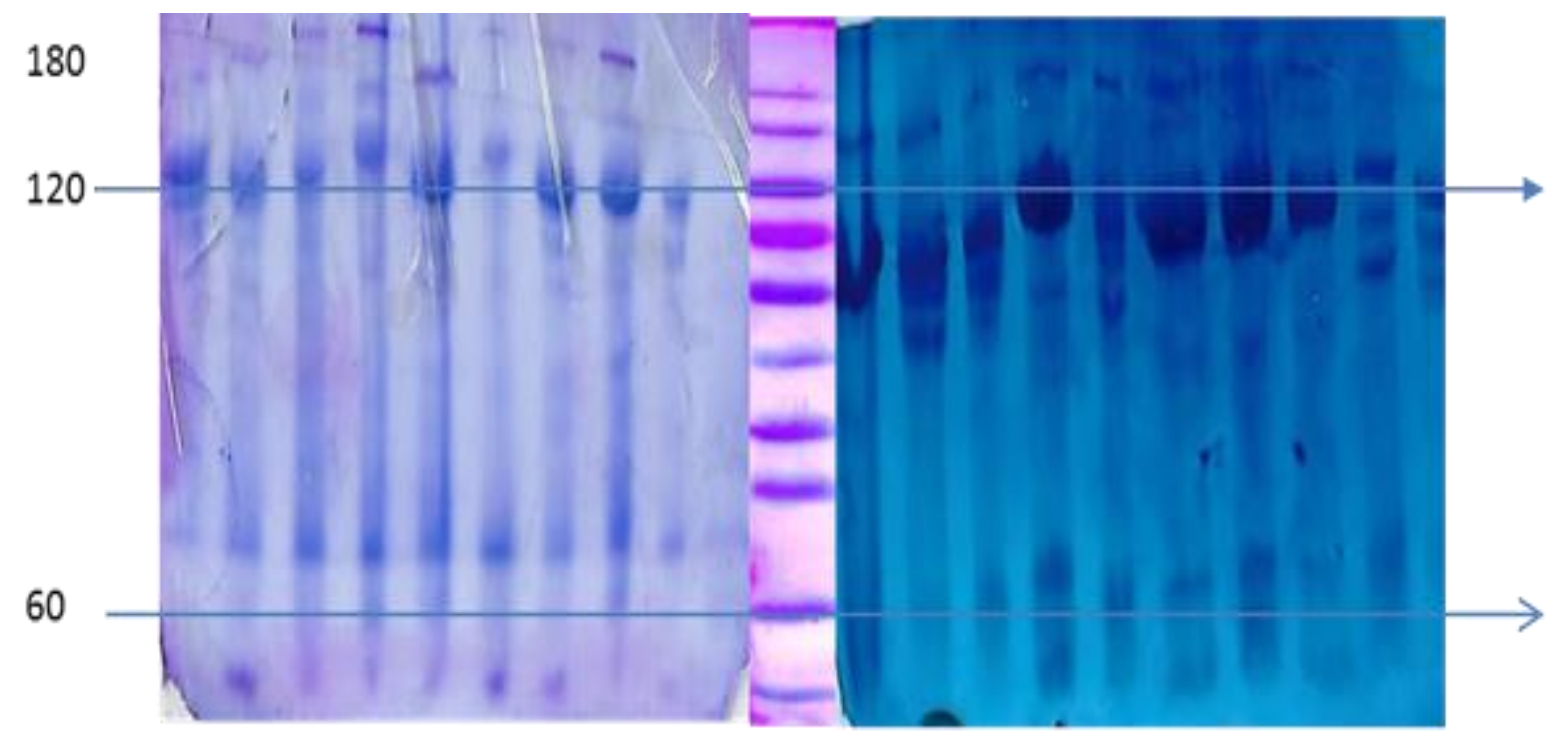

Figure 4. Electrophoregram showing protein banding pattern of barley Lines 


\section{Cluster analysis of protein}

Cluster analysis for protein bands of 40 genotype of barley, PCORD was used to construct a dendrogram tree for twelve bands. As result three clusters were obtained at linkage distance 25 (Figure 5). Cluster1 contain 16 genotypes cluster 2 contains only 14 genotype and cluster 3 contain 10 genotypes out up 40. Cluster1 had (B01, B02, B03, B05, B07, B08, B09, B04, B11, B06, B17, B12, B14, B16, B19, B39) cluster two had (B10, B15, B13, B34, B30m, B33, B38, B18, B31, B20c, B29, B35, B36, B37) cluster three had (B21,
B28, B32, B22, B23, B40m, B24, B25, B26, B27).

The scatter plot also draw for SDS-PAGE analysis (0-1 data) which show genetic variability among the bands of 40 genotype and also find similarity among the genotype the closely related genotype are near to each other which show similarity and far away from one and other show variation an term of bands(presence and absence of bands). The scatter plot were divided into two groups/clusters in term of direction (draw $\mathrm{x}$-axis and $\mathrm{y}$-axis, between the two xy-axis show 1 cluster, so there are 4 cluster) which show in the (Figure 6).

two way

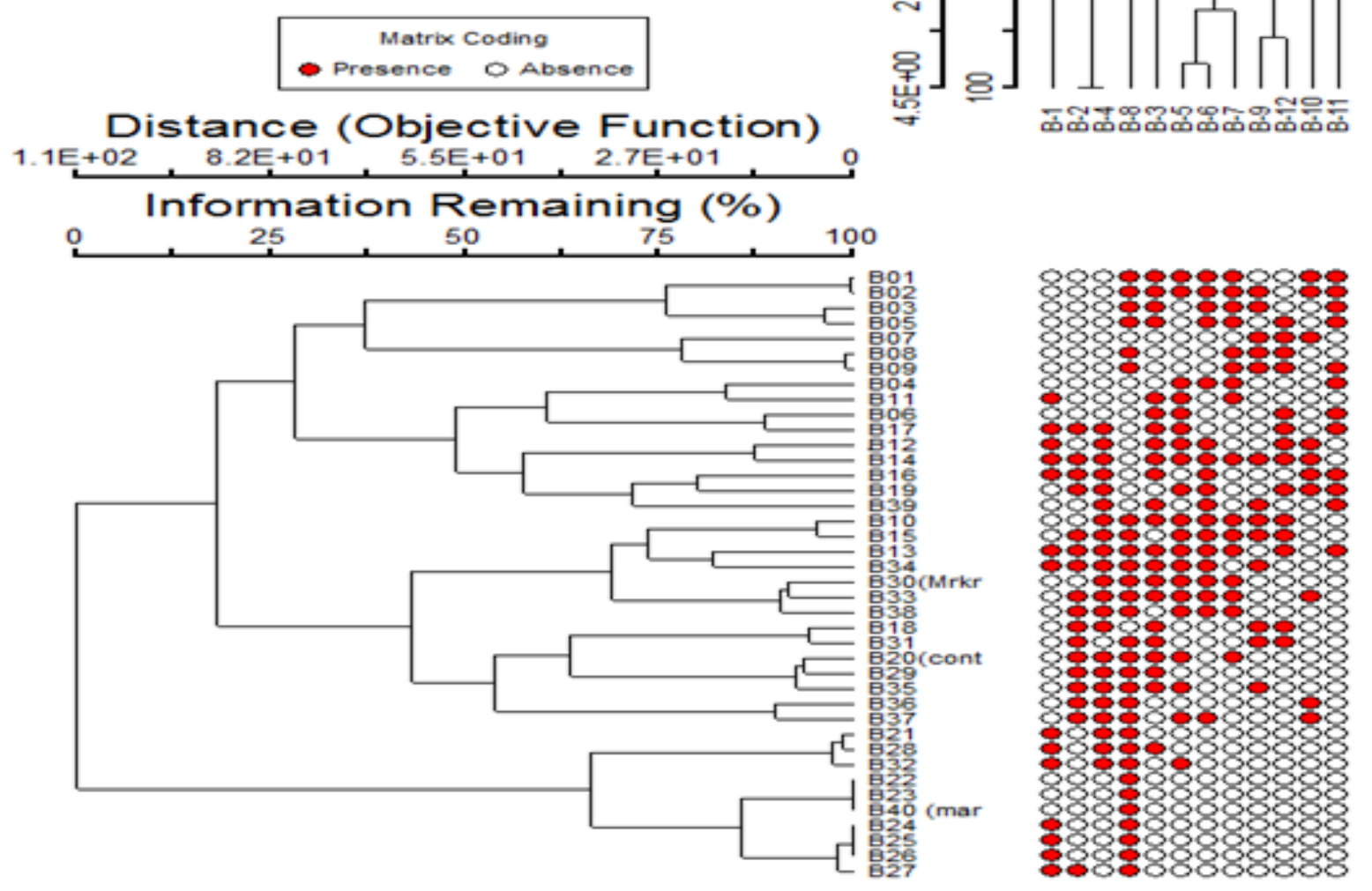

Figure 5. SDS PAGE dendogram tree for bands of 40 Lines 


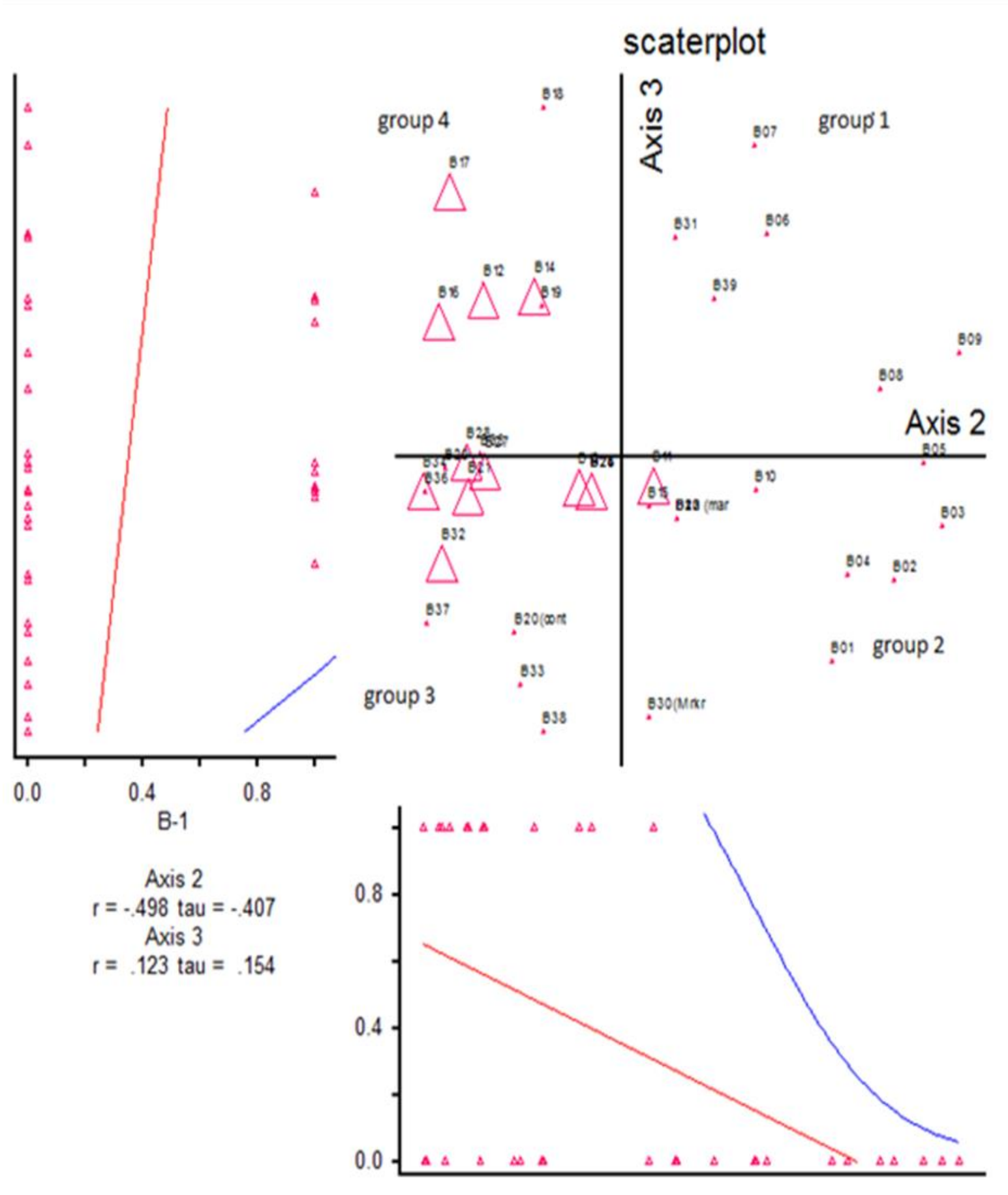

Figure 6. Scatter plot for 40 Lines of their SDS PAGE data

\section{Discussion}

In the present study 40 landraces were grown with different salinity stress applied after germination; the work is also sported by [11]. Whose genotypic differences in reaction to similar salinity stresses were reported for barley cultivars differing in salt tolerance.The objective of the study was to identify the genetic diversity among the barley germplasm with the help of morphological character and using SDSPAGE to develop high yielding verities. The morphological character are both qualitative and quantitative during present study both character was followed, during the present investigation a total of 40 
genotype of barley used for agro morphological traits. Morphological and agronomical characters of the collected germplasm facilitate in identification and selection for desirable traits [11].

In the present study, 25 character were studied which are, spike density, glume awn, lemma awn barbs, awn colour, lemma awn hood, length of rechilla hair, lemma colour, aurical pigmentation, photo period sensitivity, grain colour, stem pigmentation, kernel covering, row number, growth habit, glume colour, lemma type, days to maturity, days to flowering, plant height, spike length, seed per spike, plants per seed, biomass of per plant, 100seed weight. A significant genetic diversity was found in qualitative characters on the basis of frequency distribution. Except lemma with awns all with awns, kernel covering all were covered these traits were show no variation. For these character descriptive statistics, correlation and cluster analysis was done the quantitative traits was observed with significant variation for all the traits. For the cluster analysis a dendrogram tree was construct which composed of two linkages 1, 2 and each linkage divided into one cluster. As result two clusters were obtained at linkage distance 25.Cluster1 contain 39 genotype and cluster 2 contain only 1 genotype. The result of the present study was closely related with that of [12] studies 151 accessions for agro morphological variation. A total of 14 traits was study out of which 4 were quantitative and 10 were qualitative with a significant variation, include spike density, glume colour, awn roughness, awn colour, number of spikelet per spike, rows of per spike, glume and glume awns, kernel covering, lemma colour, rechilla hairs, grain colour, awn length, 100 seed weight, spike length.

Similarly [13] total of 22 barley landraces was collected from different farmers for agro morphological evaluation 3 parameter which show high variation in spike length, spike colour and spike type, but in case of spike length, it show high variability in spike length $(70 \%)$ from 5 to $9 \mathrm{~cm}$. [14] it was investigate the same result which was related to the present study because for morphological characterization it was take the same both qualitative and quantitative traits which show similarities and variation like present study, especially in kernel covering. [15] Also reported a wide range of variation of plant height, days to maturity, grain yield.

The correlation, mean and standard variation was calculated by using the software STATISTICA and SPSS, and observe magnificent result, among the eight quantitative traits was show strong correlation, some show intermediate and some show negative correlation toward the other character, such that, plant per grain is negatively correlated to plant height and spike length and significantly positive correlated to days to flowering and days to maturity, grain per spike is strongly positive correlated to plant height $(.414 * *)$ and significantly negative correlated todays to flowering $(-.381 *)$ while significantly positive correlated to days to maturity $\left(.375^{*}\right)$, biomass per plant is significantly positive correlated to plant height, days to flowering, days to maturity and spike length, while negatively correlated to plant per grain and strongly positive correlated to grain per spike $\left(.446^{* *}\right), 100$ seed weight is positively correlated to all. A total of 36 correlation coefficient values were observed in which 29 were positive $(80.55 \%)$ and 7 values (19.44\%) showed negative correlation. [16] Also reported the same result for the positive and negative correlation of the barley germplasm for this study he used 63 genotypes for agromorphological and biochemical variation among barley germplasm. [17] Also investigate the same result of correlation for quantitative traits of 20 genotype of barley germplasm. Similar results for grain yield and plant height in barley were reported by other [18].

In the present study of the cluster analysis was done for eight quantitative character of 40 genotype of barley the linkage divided 
into two cluster the cluster 1 contain 39 genotype and cluster 2 contain only 1 genotype out up 40. Cluster1 had (S001, S014, S004, S017, S003, S022, control, S002, S006, S023, S010, S012, S13, S019, S015, S032, S016, S020, S030, S035, S34, S021, S037, S011, S029, S36, S018, S033, S039, S025, S027, S005, S038, S007, S008, S024, S028, S040, S009, S026) cluster 2 had only one genotype S031. These show that mostly barley landraces show similarity and slightly difference or variation. the present investigation show relation with this, who divided the agro morphological character into seven cluster which also show similarity and variation on basis of the geographical division [18]. Reported the same result for the agromorphological traits were divided into 4 clusters [11].

\section{Biochemical assessment}

The biochemical analysis using SDSPAGE has great contribution for the estimation of genetic diversity since form a few years it was estimated that in different crop species has dependent on morphological character but now the genetic diversity is widely investigated through biochemical methods which is more benefit as compare to classical morphology For the protein profiling SDSPAGE is a biochemical technique which is widely used for identification genetic structure of different crops because it is simple, reliable and free from fluctuation [5]. The researchers approved that biochemical analysis of protein by SDSPAGE provided valid evidence for detecting intra specific variation and assessing inter specific relationships.

During present study total of 40 landraces was collected and then treated with salt stress and SDS analysis was done for all genotype in which 12 bands was observe in which two band are monomorphic and the remaining are polymorphic, Cluster analysis for protein bands of 40 genotype of barley, PCORD was used to construct a dendrogram tree for twelve bands. As result three clusters were obtained at linkage distance 25. Cluster1 contain 16 genotypes cluster 2 contains only 14 genotype and cluster 3 contain 10 genotypes. Cluster1 had (B01, B02, B03, B05, B07, B08, B09, B04, B11, B06, B17, B12, B14, B16, B19, B39) cluster two had (B10, B15, B13, B34, B30m, B33, B38, $\mathrm{B} 18, \mathrm{~B} 31, \mathrm{~B} 20 \mathrm{c}, \mathrm{B} 29, \mathrm{~B} 35, \mathrm{~B} 36, \mathrm{~B} 37)$ cluster three had (B21, B28, B32, B22, B23, B40m, B24, B25, B26, B27). Scatter plot were also draw through this software which show significant variation the closely related genotype present in the same axis in cluster form. [14] Reported 37 bands in literature. Similarly [15] was also reported the same result for protein bands a total 12 was reported. [6] Studied 23 genotypes total 21 bands were found which show variation [7].

PCA is a multivariate approach used to complement the cluster analysis information and to produce a dimensional scatter plot of the germplasm which is more informative regarding distances among the genotypes [18]. For present study PCA (scatter plot) were also draw which show variation among the landraces which divided into different group on the basis of their similarities and differences. In present study Maximum genetic diversity were observed on band 10, which are $(0.75 \%)$, while minimum genetic diversity were found on band 8 , which is $(0.28 \%)$, the variation in protein bands express the genetic diversity present in the seed storage protein. In the present study the bands were comparing with novel marker the molecular weight of the marker was $10 \mathrm{kDa}$ to 180 $\mathrm{kDa}$. The bands were divided into three zone, zone one have molecular weight from 10 to $60 \mathrm{kDa}$ zone two have molecular weight from 60 to $120 \mathrm{kDa}$ and zone three have molecular weight from 120 to 180 $\mathrm{kDa}$. Zone one contain four bands (band 12, $11,10,9$ ) zone two contain four (band 8, 7 , $6,5)$ zone three also contain four bands (band 4, 3, 2, 1). Band 5 dominantly present in zone two bands 10 is dominantly present in zone one which show significant genetic 
diversity among barley genotypes and provide the base in future for breeder.

\section{Conclusion}

It was concluded from the present investigation that maximum salinity affect the total biomass of the plant, seed weight while the spike length is not affected. Utmost variations were noted in qualitative parameters on the basis of frequency distribution. 100 seed weight and total biomass of the plant show significant variability. The total seed protein profile also shows high variation which reveals that salinity affect the proteins. This work gives help breeders and molecular research to explore the salinity stress on barley germplasm.

\section{Authors' contributions}

Conceived and designed the experiments: M Ali, Performed the experiments: S Abdullah, M Ali \& M Nisar, Analyzed the data: W Khan, M Hussain \& M Nisar, Contributed reagents/ materials/ analysis tools: W Khan, S Abdullah \& M Hussain, Wrote the paper: M ALi \& S Abdullah, Review the Paper: M Hussain, W Khan and M Nisar.

\section{References}

1. Rehman, SU, Predotova, M, Khan IA, Schlecht E \& Buerkert A (2013). Socio-economic characterization of integrated cropping systems in urban and peri-urban agriculture of Faisalabad, Pakistan. J of Agricu and Rural Devel in the Tropics and Subtropics (JARTS) 114(2): 133-143.

2. Baik BK \& Ullrich SE (2008). Barley for food: Characteristics, improvement and renewed interest. J Cereal Sci 48: 233-242.

3. Ebrahim S, Shiferaw E \& Hailu F (2015). Evaluation of genetic diversity in barley (Hordeum vulgare L.) from Wollo high land areas using agromorphological traits and hordein. African J of Biotechnol 14(22): 18861896.

4. Eshghi R \& Akhundova E (2010). Genetic diversity in hulless barley based on agromorphological traits and
RAPD markers and comparison with storage protein analysis. African $J$ of Agric Res 5(1): 097-107.

5. Fischbeck G (2002). Contribution of barley to agriculture: a brief overview. In Barley Science. Edited by GA Slafe, JL.Molina-Cano, R Savin, JL Araus, I Romagosa. Food Product Press, New Yok, London, Oxford, pp 11-12.

6. Ghafoor A, Ahmad Z \& Afzal M (2005). Use of SDS-PAGE markers for determining quantitative traits loci in blackgram [Vigna mungo (L.) Hepper] germplasm. Pak J Bot 37(2): 263-269.

7. Govindaraj $M$, Vetriventhan $M$ \& Srinivasan M (2015). "Importance of Genetic Diversity Assessment in Crop Plants and Its Recent Advances: An Overview of Its Analytical Perspectives," Genetics Research International, Article ID 431487, pp 14.

8. Kilic H, Akar T, Kendal E \& Saim I (2010). Evaluation of grain yield and quality of barley varieyies under rainfed condition. Afr J Biotechnol 9: 7825-7830.

9. Kisana NS, Tahir M, Mujahid MY, Ahmed I, Majid A, Mustafa SZ \& Ahmed Z (1999). Variability and relationship between morphophenological traits and grain yield in winter and facultative barley under stress environments. Pak J Biol Sci 2: 767-771.

10. Lasa JM, Igartua E, Ciudad FJ, Codesal P, Garcia EV, Gracia M P, Medina B, Romagosa I, Molina-Cano JL \& Montoya JL (2001). Morphological and agronomical diversity patterns in the Spanish barley correlationHereditas, 135: 217-225. Lund. Sweden. ISSN 0018-0661.

11. Lasztity R (1985). Cereal protein: Past, Present and Future. In Amino acid composition and biological value of cereal proteins (M Hidegi, R Lasztity, eds). Kluwer Academic Publishers, Hungary. 
12. Madhusweta Das \& Sumeet K (2003) Status of Barlry as a Dietary Component for Human. J of Food and Dairy Technol e-ISSN: 2321-6204 pISSN: 2347-2359.

13. Munns R, James RA \& Läuchli A (2006). Approaches to increasing the salt tolerance of wheat and other cereals. J Expt Bot 5(57): 1025-1043.

14. Mzid R, Chibani F, Ben AR, Hanana M, Breidi J, Kabalan R, El-Hajj S, Machlab H, Rebai A \& Chalak L (2016). Genetic diversity in barley landraces (Hordeum vulgare L. subsp. vulgare) originated from Crescent Fertile region as detected by seed storage proteins. J Genet 95: 733-739.

15. Niazi MLK, Mahmood K, Mujtaba SM \& Malik KA (1992). Salinity tolerance in different cultivars of barley (Hordeum vulgare L.). Biol Plant 34: 465-469.

16. Shegaw D, Elias $U$ \& Hussein $M$ (2013). Genetic Variability in Barley (Hordeum vulgare L.) Landrace Collections from Southern Ethiopia. Intl J of Sci 2319-7064.

17. Tester M, Davenport RJ (2003). Na+ transport and $\mathrm{Na}+$ tolerance in higher plants. Annals of Bot 91: 503-527.

18. Zeeshan M, Uallah Z, Ullah K, Baloch MK, Rauf A, Ullah R (2012). Evaluation of Genetic Diversity in Barley Germplasm of Khber Pakhtunkhwa and Northern Areas on the Basis of Agro Morphological and Biochemical traits. Intl J of Green and Herbal Chem 1(2): 186-202. 